\title{
Healthy Home Concept According to Javanese Ethnic Panaragan Society: An Etnolinguistic Study
}

\author{
Hujaefa Hi Muhamad ${ }^{1}$, Titi Rapini ${ }^{2}$, Sri Sugiharti ${ }^{3}$, Alip Sugianto ${ }^{4}$, Siska Diana Sari ${ }^{5}$ \\ ${ }^{1}$ Lecturer, Universitas Khairun, ${ }^{2}$ Lecturer, Universitas Muhammadiyah Ponorogo, ${ }^{3}$ Lecturer, Universitas Riau \\ Kepulauan, ${ }^{4}$ Lecturer, Universitas Muhammadiyah Ponorogo, ${ }^{5}$ Lecturer, Universitas PGRI Madiun
}

\begin{abstract}
Javanese ethnic Panaragan culture is very diverse. One of them is the traditional Javanese ethnic Panaragan home. The home as a shelter is expected to bring outer and inner health to its inhabitants. The concept of a healthy house can be known to the mindset of the people contained in language. The theory used is ethnolinguistics which views language tends to reflect the mindset of a society. The method is used ethnoscience by analyzing linguistic utterances in the realm of building a healthy house. As a result, there are outer and inner concepts before building construction, healthy house space and griyowingking concept that reflects a healthy home mindset for the comfort and safety of a residence which is summarized in language patterns.
\end{abstract}

Keywords: Home, healthy, and ethnolinguistics.

\section{Introduction}

East Java region according to the culturalist Sutarto is divided into ten cultural regions consisting of Arek Culture, Samin (SeduluSikep), Osing (Using), Pandalungan, Madura Kangean, Madura, Pulau and Madura Bawean, Jawa Mataraman, Java Panaragan. (1) From the ten cultural regions, they have distinctive characteristics, and cultural style between regions. One of the cultures of East Java in the western region that has cultural diversity is the Panaragan Javanese Ethnic Culture.

The traditional Javanese Panaragan ethnic home, has its own way of expressing a place of staying and shelter for the Panaragan community which reflects the mindset of the society regarding concepts and mythology in building a home. To building a home, the society still has confidence in the determination of a good day that takes into account aspects of the Javanese calendar

\section{Corresponding Author:}

Hujaeefa Hi Muhamad

Ternate, North Maluku

e-mail: hujaefamuhammad@gmail.com calculation (petungandino) providing earth surgical offerings (ndudokris) and geographical calculation of the layout with the hope that the homes built will become safe, comfortable, and peaceful for its inhabitants.

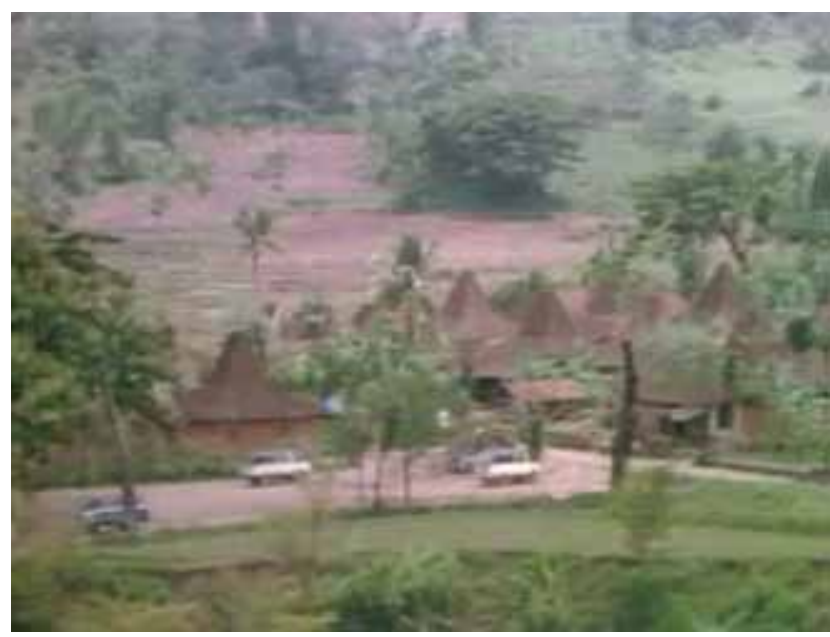

Figure 1. Traditional Home of Ethnic Java Panaragan (Reyog Ponorogo Document Archive)

In building a Javanese ethnic Panaragan home is guided by a calculation of days (numerology) which is learned from the ancestors based on life experiences that are adjusted to the events on a daily basis based on the day character (watakdino). In other words, the Panaragan Javanese Ethnic society adheres to the science of tit 
(ngelmutiten), in order to be more vigilant, cautious and careful in carrying out an action so that events that are considered not good, will not happen again in the future, avoid something that is not desirable and always get good every day from a house that is inhabited.

Daldini and Wistodiyono state that houses are not only a building for shelter and rest but according to Javanese ancestors used as a symbol of worship to Sang Hyang MahaWasesa. ${ }^{(2)}$ Thus it can be understood that Javanese society has a close relationship with mindset with a belief that expresses a form of gratitude to the creator of the universe, with the hope of life in the household ark in a house always in His shade. For this reason, the Panaragan Ethnic Javanese Society before setting up a house usually determines the best day, among other good days. On that day held a celebration of thanksgiving to God through the ritual selametan by presenting the neighbors led by warok (figure of society) or kyai (traditional religious scholar) as selametan ritual leaders who are believed to have closeness to the strength believed. This activity, carried out in the hope of obtaining the safety of the Almighty.

Besides that, in building a house, avoid locations called sunduk sate (like satay) or just in front of the three way intersection (totokan). This perception is based, because of the safety factor which is of course the location of the sunduk sate is worrying if there is an accident that usually occurs due to someone's negligence in driving a vehicle. In addition, this assumption also underlies psychologically it can disrupt the peace and tranquility of the soul for residents because every day they are faced with a vehicle that seems to go to the end of the road or called a taboo so that it is not good for the health of the owner's soul because his heart is likened to every day crash (sunduki).

Abstinence (Pantangan) in building a home in the Panaragan Javanese Ethnic society, of course has a consequence that will occur if these restrictions are violated by the society. Even though this belief is increasingly fading, some people avoid it as a precaution. Therefore, in building a house, requires some consideration of certain aspects in maintaining harmony between physical and mental health. That is, the house that will be built gives comfort and tranquility in terms of physical buildings that affect the health aspects of the householder's inner, but also gives spiritual health to the residents of the home because it brings peace and tranquility to the inhabitants. This study aims to find the relationship between language and culture in Javanese Panaragan society, especially the relationship of language and mindset that reflects the view of life in the realm of building a healthy home. Thus, the hope of the purpose of this study is expected to be achieved.

\section{Theory and Method}

The theory used in this study refers to the adjusted Sapir-Whorf hypothesis, namely, that basically language tends to reflect the mindset of a society. In other words, the language tends to reflect the ethnic mindset as contained in the knowledge system. ${ }^{(3)}$ This study uses an ethnoscience approach. The focus of attention is the principles of classification as expressed. ${ }^{(4)(5)}$ This method is applied in an effort to find activities that apply to the Panaragan Javanese society in order to find patterns related to how to build a healthy home, ways before building healthy homes, patterns of form and architecture that reflect their world view and other empirical concepts that apply on the Javanese Panaragan society.

\section{Results and Discussion}

\section{(a) The Concept of Ethnic Panaragan Inner Healthy}

Home: To create an inner healthy atmosphere, in building a house, the Javanese Panaragan ethnic society first saw the place to be used which included the location and type of land. The location that is used is safe from various possible disaster threats, such as landslides and floods that can occur naturally. These considerations are chosen carefully, so that in the future there is no unwanted thing that can harm materially and immaterially. Although every human disaster does not want, alert is the main road. The calculation of the location is an important factor because many people experience material losses in the form of assets in the event of a natural disaster or immaterial in the form of psychological psychology such as traumatic, especially if left by a loved family

Experience the history of land by the Panaragan ethnic society as one of the important elements in building a home or buying a home. Therefore, you must first know the origin and history. In building a home, the Panaragan ethnic society after determining the location and history is free from the problems, then the next step is usually by holding calculate the day (pitungdino) with the use of the Javanese calendar. The person appointed is usually called pujonggo or a friend who is believed to be smart and has the accuracy in determining the 
best day between good days or called the exspresion of linguistic nagadino.

After the process of determining the day is good, the next step is the process of surgical earth (ndudukris) in modern terms now known as the laying of the first stone by holding selametan inviting relatives and tonggoteparo to run the hajadan and prayer together to make a circular formation in the place of the house to be built like a pager with the purpose of the home to be built is to avoid danger through prayer pagers in a circle sitting cross-legged in the middle of uborampe in the form of chicken, banana, jenangsengkolo, money and eggs. This concept then becomes a life guideline for some Javanese people in building a home that is very concerned about the harmony of inner and outer, because the house is used for a long period of the time, so keeping the house into a comfortable residence is a must even though in the form of a home that is not too luxurious, but it's more important to live happily and always bring blessings.

\section{b) The concept of Physic Panaragan Ethnic} Healthy Home: The home is a physical structure consisting of room, yard and surrounding area that is used as a place of residence and means of family formation. ${ }^{(6)}$ While the understanding of houses according to WHO (World Health Organziation) is a physical structure or building for shelter, where the environment is useful for physical and spiritual health and social conditions both for family and individual health. ${ }^{(7)}$ The function of the house is as a place to let go of fatigue, socializing, fostering a sense of kinship between family members, sheltering and storing valuables, and as a symbol of social status. ${ }^{(8)}$

A healthy home is a physical structure of the building as a shelter or shelter and a place to rest so that it grows a perfect life both physically, spiritually and socially culture and free from illness or weakness (Disability). In general, the house is said to be healthy if it meets the following criteria. ${ }^{(7)}$

Physical aspects of the building for the Panaragan ethnic society have several elements of a standard healthy home. A healthy home must have several important components. Among other things are the components or structure of the house, sanitation and healthy behavior of the occupants, which are then elaborated in the form of more indicators, namely components, structure and condition of the ceiling, walls, floors, windows, bedrooms, living room windows, ventilation, holes kitchen smoke, lighting, cages, and yard utilization. From these elements, above the construction structure of the shape and space of the Javanese Panaragan ethnic house is generally the same as the other traditional Javanese traditional houses.

According to Yunitathe main home is at least composed of three masses of this building, surrounded by a wide yard. ${ }^{(9)}$ The yard consists of latarngarep, on the front, latarmburi, in the back and latarwetan and latarkulon on the side. Ngarep or front yard is an average of $10 \mathrm{~m}$ to 15 meters of roadside, serves to dry the harvest. The background (latarmburi) is large to occupy sumur, jedhingblandhong (bathroom), kakus (WC), and pawuhan (trash bins) tegalan and stables. side yard of the latarwetan is on the east side, while the latarkulon is on the west side, serves for moor or gardens and places blumbang or fish pond

\section{c. The Variety of Ornaments: Art of Architecture} and symbolic meaning: The shape of the roof of a traditional Javanese Panaragan ethnic home has an interesting variety of decoration and architecture from a certain point of view. The variety, among others, is found in the upper part of wuwungan in the Panaraganjoglo house. The position of wuwungan which has an angle and aesthetic value is a symbol of the service of the crown of the king. The ornament, sometimes resembling a tiger's ear, symbolizes the strength and dignity of a house.

The decorative model is in the form of decorations with various shapes and motifs. Soko is a foundation that serves to support the roof. Soko on the upper end usually has ornate carvings in the form of lists and carvings and at the bottom there is a umpaktampak that supports the mighty. This Soko is often in the belief of the ancients given a rope bond as a tight binding symbol of a single entity, if someone who comes then feels comfortable, like there is a brotherhood among guests who present with the home owner as a symbol of brotherly ties by visiting each other. Tumpangsari is an ornament as a form of aesthetic creation by placing tumpangsari towards the outer midhangan and overlapping towards the midhangan. According to Susilo The number of tumpangsari levels varies. ${ }^{(10)}$ The number of levels is no provision, depending on the availability of materials. which means showing the level of ability of homeowners. The use of overlapping is not mandatory, but when using overlapping the number of levels must be odd, three levels or five levels or not at all. 
The difference between tumpang and tumpangsari in addition to its position, as well as its structural aspects. Tumpangsari supports the roof, its function is related to the function of the other elements, so it cannot be replaced at any time. Tumpang functions only as a cover of the bottom roof cavity, do not support the structural system. Then tumpang can be replaced, added or reduced the level. Even carving decorations can also be given, of course the other elements of the carving must be adjusted.

\section{d. The Healthy Space: Expression of forms of air ventilation and lighting functions: Ventilation} is a process of circulating air that enters the room naturally. Air ventilation serves to keep oxygen levels intact and affect the level of humidity in a room Inside the traditional Panaragan ethnic home there are usually two windows consisting of one window on the west side and one window on the east side. This ventilation, has a philosophy of air entering from one side can come out on the other side so that the air in the room will continue to experience change and freshness for the occupants in it. In addition this ventilation also functions as lighting in the morning and evening so that at that time there is no artificial lighting as it is now, the room will remain bright even though there are no lights because the sun in the morning and evening can enter the room. This concept indirectly has implications for the health of the residents of the house because in addition to maintaining the circulation of air freshness in helping breathing can also avoid moisture which can lead to susceptibility to disease seeds. ${ }^{(11)}$ This simple concept influences the pattern of action in the expression of embodiment of a healthy home according to the Panaragan ethnic community. Therefore, usually on the side of the house there are emperkiwo and empertengen. Emperkiwo as the road to pasucen is a place to clean yourself or the bathroom and toilet As for empertengen as the road to the pawon and storing agricultural products such as grain, casava, and corn

\section{Conclusion}

The concept of a healthy home according to the Panaragan Javanese community is that there are two standards that become unity, namely the concept of inner health and outer health. The concept of inner health is reflected in the expression of language in determining the day before building a house by determining the best day by performing a petungandino tradition at the time of the earth in the hope that the house to be built brings blessing During this process, the Ponorogo society also held a salvation as a form of gratitude to God by holding a prayer together inviting the brothers, relatives and neighbors to join together to win the divine blessing of God. As for outwardly the concept of healthy ethnic panoramic house is reflected in the safe construction, ornamental variety as a form of symbolization that reflects hope and prayer, healthy space with adequate ventilation and lighting, clean floors, and sanitation facilities that are protected from pollution and landfills which is adequate as a form of behavior to maintain the health of its inhabitants. The concept that is actualized becomes an integral unity to realize a healthy home avoiding various kinds of hazards, and diseases that can be caused by lack of concern for health factors.

\section{Conflict of Interest: No}

\section{Ethical Clearance: Yes}

\section{Source of Funding: Authors}

\section{References}

1. Sutarto A. Studipemetaankebudayaan Jawa Timur studideskriptifpembagian 10 sub kebudayaan Jawa Timur (The mapping study of the cultures in East Java: The descriptive study on the 10 sub-culture divisions in East Java). Jember: Program StudiAntropologi, FisipUnej;2004.

2. Wistodiyono \& Daldini.Ilmuslamet (Merangkaimutiarafilsafat Jawa di era moderinisasi dan globalisasi) (The knowledge of safety: The Javanese philosophy in the modernization and globalization era). Jakarta: PT Bhuana IlmuPopuler; 2010.

3. Fernandez IY. Sakit dan sehatdalampandangan orang Bantik dan Tonsawang: Studietnolinguistik di Sulawesi Utara (Sick and healthy in the perspective of Bantik and Tonsawang people: The ethnolinguistic study in North Sulawesi). Yogyakarta: Universitas Gadjah Mada; 1998.

4. Frake CO. Culture ecology and ethnography. American Antropologist. 1962;5(64):53-59.

5. Sturtevant WC. Studies in ethnoscience. In: Romhey AK and D'Antrate RGD. Anthropologist: Social Publication. 1964;67(5).

6. Mukono HJ. Prinsipdasarkesehatanlingkungan (The basic principles of environmental health). Surabaya: Airlangga University Press; 2000. 
7. The Republic of Indonesia's Department of Health. Pedomanteknispenilaianrumahsehat (The technical assessment guide of the healthy home. Jakarta: The Republic of Indonesia's Department of Health; 2007.

8. Maru'fi I. Rumahadat Using: Pembacaandarisudutpandangrumahsehat (Using customary home assessment from the perspective of a healthy home). Yogyakarta: Penerbit Ombak; 2016.
9. Yunita, et al. PerubahanruangberbasistradisirumahJawaPanaragan di desa Kaponan (Room rearrangement based on the Panaragan Javanese home tradition in Kaponan village). J Langkau Bentang. 2017;4(1).

10. Susilo GA. Ragam Hias Joglo Ponorogo (Decorations of Ponorogo Houses). Jurna ITesa Arsitektur. 2014;12(1).

11. Sugianto A. Eksotikapariwisata Ponorogo (The exotics of Ponorogo tourism). Yogyakarta: Samudra Biru; 2015. 